\title{
Atenção Qualificada Durante o Parto
}

Estimativas indicam que a cada ano ocorrem 120 milhões de gestações no mundo. Mais de 500.000 mulheres morrem em decorrência de complicações na gravidez, parto e puerpério. Mais de 50 milhões de mulheres sofrem doenças ou seqüelas relacionadas com a gravidez, e pelo menos 1.200.000 de recém nascidos morrem por complicações durante o parto.

A iniciativa global por uma Maternidade Segura foi lançada em 1987 como resposta a este grave problema de saúde pública. Visa promover ações para obtenção de gestações e partos mais seguros para as mulheres e os recém nascidos.

Em 1997, o Grupo Interagencial por uma Maternidade Segura, convocou conferência internacional com o objetivo de examinar as lições apreendidas durante o primeiro decênio da iniciativa, identificar as estratégias mais eficazes e mobilizar a ação em nivel nacional para implementar estas estratégias.

Nesta conferência surgiu consenso sobre o valor da atenção qualificada durante o parto, intervenção fundamental para que as gestações e os partos sejam mais seguros.

A atenção qualificada é o processo pelo qual uma mulher grávida e seu filho recebem os cuidados adequados, durante a gravidez, trabalho de parto, puerpério e período neonatal, e que o parto tenha ocorrido em uma maternidade, que é o local adequado e seguro para o evento.

Para que isto ocorra, o provedor deve ter as diretrizes necessárias e contar com o apoio dos vários setores do Sistema de Saúde. Isto inclui um marco de políticas e normas, medicamentos, equipamentos e infraestrutura eficiente de um sistema de referência.

A atenção qualificada inclui cuidados com as mulheres que tenham complicações, com risco de morte, não se limitando porém a esta situação. O enfoque da atenção qualificada se fundamenta na premissa de que todas as mulheres têm direito à atenção de qualidade durante o parto por pessoal capacitado e qualificado e em local apropriado. Isto é o Projeto Maternidade Segura.

\section{A Diretoria}

